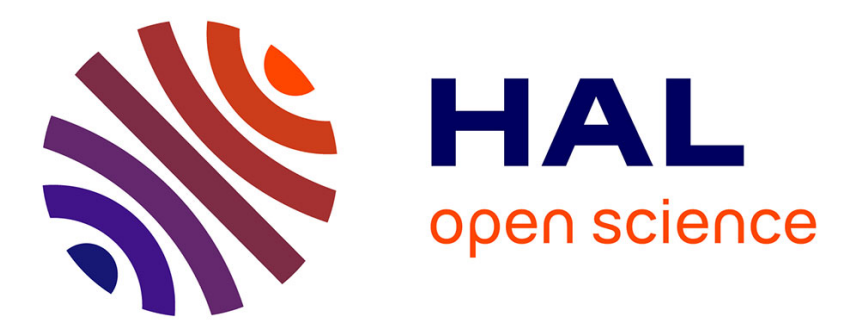

\title{
Water Usage Charge in Brazil: Emergy Donor-Side Approach for Calculating Water Costs
}

\author{
Helton Silva, Silvia H. Bonilla
}

\section{To cite this version:}

Helton Silva, Silvia H. Bonilla. Water Usage Charge in Brazil: Emergy Donor-Side Approach for Calculating Water Costs. IFIP International Conference on Advances in Production Management Systems (APMS), Sep 2016, Iguassu Falls, Brazil. pp.106-112, 10.1007/978-3-319-51133-7_13 . hal01615763

\section{HAL Id: hal-01615763 \\ https://hal.inria.fr/hal-01615763}

Submitted on 12 Oct 2017

HAL is a multi-disciplinary open access archive for the deposit and dissemination of scientific research documents, whether they are published or not. The documents may come from teaching and research institutions in France or abroad, or from public or private research centers.
L'archive ouverte pluridisciplinaire HAL, est destinée au dépôt et à la diffusion de documents scientifiques de niveau recherche, publiés ou non, émanant des établissements d'enseignement et de recherche français ou étrangers, des laboratoires publics ou privés. 


\title{
Water Usage Charge in Brazil: Emergy Donor-Side Approach for Calculating Water Costs
}

\author{
Helton R. O. Silva, Silvia H. Bonilla \\ ${ }^{1}$ University Paulista, São Paulo, Brazil \\ shbonilla@hotmail.com
}

\begin{abstract}
The Federal Water Law 9433 enacted in 1997 gave the legal frame relative of the water usage charge. The aim of this paper is to interpret legal terms through the emergy environmental accounting approach in order to establish the donor-side costs related to water usage under the user-pays and polluter-pays principles. The procedure was performed for agricultural activities at the JundiaiMirim Basin, located at São Paulo State, Brazil. The proposed procedure resulted in costs comparable to those already implemented at the watershed under study by using other economical procedures.
\end{abstract}

Keywords: Water charges · Brazilian Law 9433 - Polluter-pays principle

\section{Introduction}

In Brazil, payment for water had been already foreseen by the first water resources management legislation, the Federal Water Code, enacted in 1934. But it was the Federal Water Law (FWL) 9433 enacted in 1997 [1] that gave the legal frame for water usage charge. The Law also defines that water is a scarce resource, which has economic value, and recognizes the existence of multiple water uses and user rights. Only users who exploit water with economic benefits are subjected to charges. Another essential characteristic given by this legal document is the legitimation of the River Basin Committee to arbitrate in the first instance level conflicts in the watersheds, to implement methodologies to establish water charge values and to propose those values to the National Agency (ANA).

Complementarily, the National Environmental Policy through the Law 6938/81 had already imposed "recuperation and/or compensation to polluters and predators for caused damages as well as payment to users for the environmental resources when used for economic purposes", reflecting the polluter-pay and the user-pay principles [2].

Some basins have already implemented the management instruments targeted at the Water Resource Management Policy (WRMP), including the fixation of the water usage charge. The PCJ basin (Piracicaba, Capivari, Jundiai basin) is an example of a basin that makes progress implementing all the necessary instruments for water managements. The PCJ basin adopted a weighted coefficients methodology to fix the usage charges. The objective of this work is not making a judgment on the criterion adopted

adfa, p. 1, 2011.

(C) Springer-Verlag Berlin Heidelberg 2011 
but offering a proposal capable to unify criteria among the different basins with a background theory to sustain the accounting.

To capture the economical value of natural resources is not easy and some economical instruments have been proposed with more or less success [3]. Motta [4] recognized the difficulty of fixing natural resources market prices that properly reflect the value assigned to them. Furthermore, he emphasizes [4] that each analyst will assume different hypothesis according to the valuation object, data availability and knowledge of the ecological dynamic of the resource.

The emergy accounting, based on thermodynamics and systems theory provides an approach to evaluate natural resources contribution to society, by calculating the biosphere work directed to generate them and make them available. In this way, all type of natural resources can be evaluated and quantified with the same basis: biosphere cost in the form of solar energy. The state of water resources and the pressure exerted by human activities in Chinese cities [5], as well as the value of water resources in Chinese rivers [6] and Italian watershed [7] was studied using emergy. The methodology was proposed to capture the recovery cost for water usage within the Water Frame Directive (WFD) definitions [8]. Differently from the Brazilian water administration, the WFD provides a framework of definitions with the purpose of identifying the different kinds of water use costs (services, resources and environmental costs). Brazilian directive enables a broader interpretation of the terms involved since the extent of the use (UPP) and pollution-pays principle (PPP) is not completely defined. Kind of water usages subjected to charges include only those relative to water grant. Whether or not externalities should be included into the PPP or only direct pollution costs depends on the analyst expertise or interpretation, social interests or basin committee considerations, making difficult to propose a unified method to quantify charges. Different legal interpretations arise from the broad approach of the definitions and in order to establish a criterion, in the present work, the extent of the environmental effects due to usage included the externalities caused due to enterprises operation.

The aim of this paper is to make an interpretation of the WRMP in terms of the emergy theory in order to establish the costs related to water usage under the UPP and PPP. Since the scenarios of usage are diverse only the agricultural case is shown and discussed here. Quantification for the other scenarios is in advance. Data from JundiaiMirim basin are employed for calculation. Selection of the Jundiai-Mirim watershed, a management unit (unit $\mathrm{n}^{\circ}$ ) that belongs to the JPC basin, as a case study was done since the macro-basin has a well-organized system of usage charge.

\section{$2 \quad$ Materials and Methods}

\subsection{Emergy Accounting}

Emergy is defined as the available energy of one kind previously used up directly and indirectly to make a service or a product [9]. A complete assessment of the methodology cannot be provided here, but the reader can refer to published reports [9]; [10].

In contrast to economic valuation, which has a user-side approach giving into account the users willingness-to-pay, emergy accounting provides a donor-side approach, 
quantifying the cost of nature to generate a service. From that cost quantification, the methodology can translate cost into currency flows, creating the interface with economy.

In order to calculate the emergy of a resource, the quantity expressed in units of energy is determined and multiplied by its correspondent "transformity". "Transformity", expressed in seJ/J, is the factor to convert energy inputs in emergy and it represents all past environmental work necessary to obtain one joule of a given resource. When inputs are expressed in mass or money, the specific emergy or the emergy-money-ratio (EMR) is used to convert values into solar energy joules (seJ), respectively. The emergy-money-ratio used in this study was calculated by dividing the annual emergy (in seJ/y) of the São Paulo state economy by its gross national product $(\mathrm{R} \$ / \mathrm{y})$. On the contrary, conversion of emergy to currency is accomplished by dividing emergy values by the EMR corresponding to the economy where the study is conducted. The units derived from the division are defined as emR $\$$ (em-real, real is the Brazilian currency) and serve to make an analogy with currency.

The emergy flows are classified into three categories of resources: $\mathrm{R}$ as renewable resources, $\mathrm{N}$ as non-renewable resources and the inputs provided by the economy, $\mathrm{F}$.

The theory In order to carry out emergy flux determination, the planetary baseline of $15.83 \times 10^{24} \mathrm{seJ} /$ year was adopted [11]; [12]. The transformity values that were calculated using another baseline were corrected and properly informed during calculation.

\subsection{Interpreting Law Terms trough the Emergy Approach}

When the emergy approach is used to interpret the terminology employed by the WRMP, two kinds of costs emerged, usage costs, related to the UPP and those derived by the PPP concept.

UPP-related costs of water correspond to the quantity of water diverted and used to carry out the enterprise, in this case, for agriculture production. Although it is true that a parcel of the diverted water is not directly used and returned to the water-body or infiltrates, it will suffer modification if compared to the initial conditions. The natural water cycle is the responsible of the water presence at the basin, so the emergy costs can be assimilated to the emergy of the water itself. Geopotential energy and chemical potential energy are the two main components of emergy, of water and derived from rainfall onto the watershed area. In this way, CUPP (expressed in seJ/m3), the emergy usage cost, is defined as the emergy flow (Emrain) related to geopotential or chemical potential aspects of rain distributed through the whole volume of water (wrain) within the watershed, CUPP $=$ Emrain/wrain. The division of CUPP by EMRSP converts emergy to equivalent monetary values, expressed in emR $\$$.

PPP related costs of water are considered here as those related to alteration of the physical and biological aspects of water bodies due to human activities of water usage. The usage of water in agricultural activities directs not only water but also other inputs, nonrenewable resources and market goods that generate a load in the used land [13]. The excess of local emergy density created as a consequence of the load from water usage used is then distributed through superficial and ground water along the watershed 
causing interference of water bodies. Accounting of these effects are calculated by $\mathrm{CPPP}=\mathrm{EmN}+\mathrm{F} / \mathrm{wdisch}$, (expressed in seJ $/ \mathrm{m} 3$ ) being $\mathrm{EmN}+\mathrm{F}$ the annual emergy flow of nonrenewable and purchased inputs involved in agricultural activities at the region and wdisch the volume of discharge water of the watershed (that portion of water that is not involved in evapotranspiration). The CPPP expression implies in the distribution of the load caused by the convergence of $\mathrm{N}$ and $\mathrm{F}$ inputs per area through the total volume of discharge water. Analogously, division of CPPP by EMRSP offers an emR \$ value that can be considered as currency and compared to actual prices.

\subsection{Calculation considerations}

For the emergy flow $\left(\mathrm{Em}_{\mathrm{rain}}\right)$ calculations, the higher of the two flows from geopotential and chemical potential was selected in order to avoid double accounting according to the Emergy Theory-algebra [9]. In this case, chemical potential emergy flows were used.

Since no data about volume of groundwater in the watershed is available, for the $\mathrm{w}_{\text {disch }}$ estimation the hydro balance of the region was used by means of the specific discharge value of $10.01 / \mathrm{s} \mathrm{km}^{2}$ from [14].

The $\mathrm{Em}_{\mathrm{N}+\mathrm{F}}$ derives from the annual areal emergy intensity (expressed in seJ/ha y) of each kind of agricultural activity at the region multiplied by the area occupied by each activity (in ha). Two kinds of calculations were adopted in order to estimate the $\mathrm{Em}_{\mathrm{N}+\mathrm{F}}$ value. From these two calculations two values of cost will arise which could be considered as the upper and lower limits of the cost interval. It is difficult to evaluate the extent and intensity of the damages exerted by human activities to water bodies and nature in general. Also, to establish the area that has direct influence on damages and disturbance is not trivial. In order to establish an interval of influence, two regions were considered to carry out calculation: the activities occurring at the permanent protection areas (PPA) and activities at the whole watershed. Activities occurring in both regions considered generate load due to the intensity increase of nonrenewable resources. Although it seems that those occurring at the PPA will create more disturbance, activities at the whole watershed certainly will also contribute.

\subsection{Jundiai-Mirim Micro-watershed}

The Jundiai-Mirim River watershed belongs to the São Paulo state, Brazil. It presents an area of $117.50 \mathrm{~km}^{2}$ and is located within parallels $23^{\circ} 00^{\prime}$ and $23^{\circ} 30^{\prime} \mathrm{S}$ and meridians $46^{\circ} 30^{\prime}$ and $47^{\circ} 15^{\prime} \mathrm{W}$. Jundiai-Mirim River has $16 \mathrm{~km}$ extension and is one of Jundiai River affluent. Diverse anthropogenic activities occur at the basin. 


\section{Results and Discussion}

The evaluation of the UPP-related costs of the resource was performed by calculating the chemical potential energy in a yearly basis. Table 1 shows the $\mathrm{C}_{\mathrm{UPP}}$ in emergy values and their conversion to currency.

Table 1. The chemical potential energy of water, transformity value, emergy UPP-related cost of water and the cost expressed in currency.

\begin{tabular}{|c|c|c|c|c|}
\hline & $\begin{array}{c}\text { Chem. pot. Energy* } \\
\left(\mathbf{J} / \mathbf{m}^{\mathbf{3}}\right)\end{array}$ & $\begin{array}{c}\text { Transformity } \\
(\text { (se J/J) }\end{array}$ & $\begin{array}{l}\text { CupP } \\
(\mathbf{s e J} / \\
\left.\mathbf{m}^{3}\right)\end{array}$ & 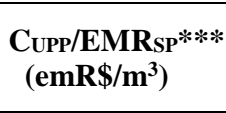 \\
\hline $\begin{array}{l}\text { Basin } \\
\text { water }\end{array}$ & $4.94 \mathrm{E}+06$ & $\begin{array}{l}3.106 \mathrm{E}+04 \\
* *\end{array}$ & $\begin{array}{l}1.53 \mathrm{E} \\
+11 \\
\end{array}$ & 0.89 \\
\hline
\end{tabular}

*from V x d x G, being V=1 ${ }^{3}, \mathrm{~d}=1.0 \mathrm{E}+06 \mathrm{~g} / \mathrm{m}^{3}$ water density, $\mathrm{G}$ (Gibbs free energy)= $4.94 \mathrm{~J} / \mathrm{g}$, assuming rain water with $10 \mathrm{ppb}$ of dissolved solids; ** from [12]; *** EMRSP $=1.7 \mathrm{E}+12 \mathrm{seJ} / \$$, from [15].

To estimate the PPP-related costs of water, the disturbance caused by the agricultural activities was calculated. Table 2 shows the upper and the lower values of the interval. The upper limit is almost 7 times greater than the lower load due to agricultural activities. To obtain CPPP, division by the discharge water $(101 / \mathrm{s} \mathrm{km} 2 \times 117.5 \mathrm{~km} 2)$ was done, as shown in Table 3 . To convert these values into currency, they were multiplied by the EMRSP (1.7E+12 seJ/\$, from [15]), see Table 3 .

Table 2. The EmN+F (the annual emergy flow of nonrenewable and purchased inputs involved in agricultural activities) for the agricultural activities performed at the PPA and in the whole watershed.

\begin{tabular}{lccccc}
\hline $\begin{array}{l}\text { Agricultural } \\
\text { activity }\end{array}$ & $\begin{array}{l}\text { Area } \\
\text { PPA (ha)* }\end{array}$ & $\begin{array}{l}\text { Total } \\
\text { Area } \\
\text { (ha)* }\end{array}$ & $\begin{array}{c}\text { Areal } \\
\text { Emergy Intensity } \\
\text { (sej/ha y)** }\end{array}$ & $\begin{array}{c}\text { PPA Em }+ \text { +F } \\
(\mathbf{E 1 5 s e J /} / \\
\text { y) }\end{array}$ & $\begin{array}{c}\text { Total Em }+\mathbf{F} \\
(\mathbf{E 1 5 s e J / y )}\end{array}$ \\
\hline $\begin{array}{l}\text { General agri- } \\
\text { culture }\end{array}$ & 51.2 & 522.7 & $1.26 \mathrm{E}+15$ & 64.5 & 658.6 \\
Row crops & 8.4 & 682.8 & $2.34 \mathrm{E}+15$ & 19.7 & 1597.8 \\
pasture & 574.1 & 2781 & $1.08 \mathrm{E}+15$ & 620.0 & 3003.5 \\
$\begin{array}{l}\text { Tree planta- } \\
\text { tion }\end{array}$ & 295.8 & 1683.9 & $2.44 \mathrm{E}+15$ & 721.8 & 4108.7 \\
total & & & & 1426.0 & 9368.6 \\
\hline
\end{tabular}

* Values are taken from [16]; **Values are taken from [17]. 
Table 3. The $C_{P P P}$ values expressed in emergy and the value expressed in currency for the agricultural activities performed in the PPA (lower limit) and in the whole watershed (upper limit).

\begin{tabular}{ccc}
\hline & Lower limit & Upper limit \\
\hline $\left.\begin{array}{c}\mathrm{C} \text { PPP } \\
\left(\mathrm{E}+09 \mathrm{seJ} / \mathrm{m}^{3}\right)^{*} \\
\begin{array}{c}\mathrm{C} \\
(\mathrm{PPP} / \mathrm{EMRS}\end{array}\end{array} \mathrm{m}^{3}\right)^{* *}$ & 38.4 & 252.5 \\
$(\mathrm{emR} \$ / 022$ & 0.146 \\
\hline
\end{tabular}

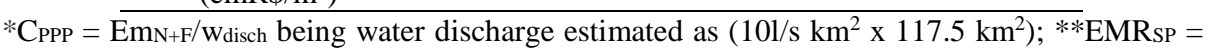
$1.7 \mathrm{E}+12 \mathrm{seJ} / \$$, from [15].

The values calculated here for water charging pricing are comprised within the interval 0.91 and $1.04 \mathrm{emR} \$ / \mathrm{m}^{3}$ for agricultural uses. They are computed as the sum of the two emergy costs after conversion to monetary values. Comparison with the results derived from the emergy approach performed for the Spanish basin [8], shows comparable but lower values for the present case study. On the other hand, the procedure already implemented at the PCJ committee, fixed basic unitary prices from of 0.01 to $0.10 \mathrm{R} \$ / \mathrm{m}^{3}$ for catching and organic load, respectively.

\section{Concluding Remarks}

The emergy approach offers a tool to aid in water usage charge estimation. It provided a systemic point of view that in the present case results in costs comparable to those already implemented at the whole PCJ macro-basin, when the Jundiai-Mirim microbasin is located. Although the charge of water due to usage and pollution is still a controversial topic, the present work evidences that the whole biosphere contributes trough concentration of free natural resources to maintain the hydrological cycle and offer ecoservices to anthropogenic activities.

\section{Acknowledgments}

Helton R. O. Silva wants to recognize the CAPES-PROSUP master degree scholarship.

\section{References}

1. Brazil. Law 9433, http://www.ana.gov.br/Legislacao/default2.asp

2. Brazil. Law 6938/81, http://www.planalto.gov.br/ccivil_03/Leis/L6938.htm.

3. Cánepa, E. M., Pereira, J. S., Lanna, A. E. L.: A Política de Recursos Hídricos e o Principio Usuário-Pagador (PUP). Revista Brasileira de Recursos Hídricos 4(1), 103-117 (1999)

4. Motta, R. S.: Valoração e Precificação Dos Recursos Ambientais Para Uma Economia Verde. Política Ambiental, Belo Horizonte (2011) 
5. Lv, C, Wu, Z.: Emergy Analysis of Regional Water Ecological-Economic System. Ecological Engineering 32, 703-7010 (2009)

6. Chen, D, Chen, J, Luo, Z., Lv, Z.: Emergy Evaluation of the Natural Value of Water Resources in Chinese Rivers. Environmental Management 44, 288-297 (2009)

7. Pulselli, F.M., Patrizi, N., Focardi, S.: Calculation of the Unit Emergy Value of Water In A Italian Watershed. Ecological Modelling 222, 2929-2938 [2011]

8. Brown, M.T., Martínez, A., Uche, J.: Emergy Analysis Applied to The Estimation of The Recovery of Costs For Water Services Under the European Water Framework Directive. Ecological Modelling 221, 2123-2132 (2010)

9. Odum H.T.: Environmental Accounting: Emergy and Environmental Decision Making. John Wiley \& Sons Ltd, New York (1996)

10. Brown, M. T, Ulgiati, S.: Emergy Evaluation of The Biosphere and Natural Capital and Biosphere Services. Ambio, 28(6), 486-493 (1999)

11. Odum H.T.; Brown M.T.; Brandt-Williams S. Introduction and Global Budgets, Folio \#1. University of Florida (2000)

12. Odum H.T. Emergy of Global Processes, Folio \#2. University of Florida (2000)

13. Brown, M.T., Vivas, B.:Landscape Development Intensity Index. Environmental Monitoring and Assessment 221(101), 289-309 (2005)

14. Giansante, A. E, Belli, P.: Medidas de Proteção da Bacia Hidrográfica do Rio Jundiaí, http://www.bvsde.paho.org/bvsAIDIS/PuertoRico29/giansante.pdf

15. Demétrio, F. J. C.: Avaliação de Sustentabilidade Ambiental do Brasil com a Contabilidade em Emergia. Tese de Doutorado, Universidade Paulista (2011)

16. Freitas, E. P.: Análise Integrada do Mapa de Uso e Ocupação das Terras da Microbacia do rio Jundiaí-Mirim para Fins de Gestão Ambiental. Tese de Doutorado, Instituto Agronômico de Campinas (2012)

17. Agostinho, F. D. R.: Estudo da Sustentabilidade dos Sistemas de Produção Agropecuários da Bacia Hidrográfica dos rios Mogi-Guaçú e Pardo Através da Análise Emergética. Tese de Doutorado, Universidade Estadual de Campinas (2009) 